\title{
The role of probiotics and prebiotics in inducing gut immunity
}

\author{
Angélica T. Vieira ${ }^{1}$, Mauro M. Teixeira ${ }^{1}$ and Flaviano S. Martins ${ }^{1,2}$ \\ 1 Immunopharmacology Group, Department of Biochemistry and Immunology, Institute of Biological Sciences, Federal University of Minas Gerais, Belo Horizonte, \\ Brazil \\ 2 Department of Microbiology, Institute of Biological Sciences, Federal University of Minas Gerais, Belo Horizonte, Brazil
}

\section{Edited by:}

Cecil Czerkinsky, Göteborg University

Institute of Biomedicine at

Sahlgrenska Academy, Sweden

Reviewed by:

Wim Van Den Broeck, Ghent

University, Belgium

Paul Licciardi, Murdoch Childrens

Research Institute, Australia

Kuldeep Chattha, The Ohio State

University, USA

\section{${ }^{*}$ Correspondence:}

Angélica T. Vieira, Department of

Biochemistry and Immunology,

Institute of Biological Sciences,

Federal University of Minas Gerais,

Avenue Antônio Carlos, 6627 - Caixa

Postal: 486, Belo Horizonte, Minas

Gerais 30270-910, Brazil

e-mail: angelicathomaz@icb.ufmg.br
The gut immune system is influenced by many factors, including dietary components and commensal bacteria. Nutrients that affect gut immunity and strategies that restore a healthy gut microbial community by affecting the microbial composition are being developed as new therapeutic approaches to treat several inflammatory diseases. Although probiotics (live microorganisms) and prebiotics (food components) have shown promise as treatments for several diseases in both clinical and animal studies, an understanding of the molecular mechanisms behind the direct and indirect effects on the gut immune response will facilitate better and possibly more efficient therapy for diseases. In this review, we will first describe the concept of prebiotics, probiotics, and symbiotics and cover the most recently well-established scientific findings regarding the direct and indirect mechanisms by which these dietary approaches can influence gut immunity. Emphasis will be placed on the relationship of diet, the microbiota, and the gut immune system. Second, we will highlight recent results from our group, which suggest a new dietary manipulation that includes the use of nutrient products (organic selenium and Lithothamnium muelleri) and probiotics (Saccharomyces boulardii UFMG 905 and Bifidobacterium sp.) that can stimulate and manipulate the gut immune response, inducing intestinal homeostasis. Furthermore, the purpose of this review is to discuss and translate all of this knowledge into therapeutic strategies and into treatment for extra-intestinal compartment pathologies. We will conclude by discussing perspectives and molecular advances regarding the use of prebiotics or probiotics as new therapeutic strategies that manipulate the microbial composition and the gut immune responses of the host.

Keywords: prebiotics, probiotics, gut inflammation, microbiota, mucosal immunity

\section{INTRODUCTION}

The gut associated lymphoid tissue is the largest in the body, and mature lymphocytes in the gut mucosa vastly outnumber those in the bone marrow (1). Large amounts of antigens pass through the gut daily, making the gut mucosa the major site of lymphocyte contact with antigens in the entire body. In addition, approximately 100 trillion bacteria are associated with our gastrointestinal tract. This rich gut microbial community referred to as the microbiota has coevolved in a symbiotic relationship with the human intestinal mucosa in such a way that the indigenous microbiota is essential for gut homeostasis $(2,3)$. The microbiota are considered a "super-organism" and are an integral part of the gastrointestinal tract (4).

Numerous functions are ascribed to the microbiota in the human gut. These partners act similarly to an organ that can provide nutrients and help the host to digest foods, including extraction of additional calories from and metabolism of complex carbohydrates to generate short-chain fatty acids (SCFAs). Furthermore, the gut microbial community is akin to a safeguard of our health because the microbiota compete (for space and nutrients) with potential pathogens and induce the secretion of antimicrobial peptides through interaction with intestinal epithelial cells
$(5,6)$. The gut microbiota can also stimulate the differentiation and proliferation of epithelial cells, which regulate intestinal homeostasis (7-9).

The contributions of the gut microbiota to the development of the immune system have been extensively characterized. There is coordinated cross talk between the gut microbiota and the immune system, allowing the host to tolerate the large amount of antigens present in the gut. Much evidence has highlighted the role of the microbiota in health and disease. The advances in current knowledge of gut microbial biodiversity allow us to understand the mechanisms of how different microorganisms influence host function and these mechanisms' impact. Altered microbiota (dysbiosis) are associated with gastrointestinal disorders, but more recently, we observed microbial imbalance associated with broad diseases that are not restricted to the gastrointestinal tract (10, 11). The newest evidence shows that the gut microbial composition is associated with malnourishment (which causes one of the highest rates of child mortality in the world) in children from Malawi in southern Africa (12). In this work, Smith and colleagues transplanted the gut microbiota of a malnourished twin with kwashiorkor into germ-free (GF) mice (which are devoid of microbiota) and observed that these animals lost more weight 
than mice transplanted with the healthy twin's bacteria. Previously, the association of the gut microbiota with metabolic diseases was demonstrated by the same group, which showed that alterations in the gut microbiota could affect human obesity $(13,14)$. However, the composition and functional characteristics of a healthy gut microbiota remain to be elucidated.

Strategies that try to restore the normal gut microbiota have been extensively studied in human and animal models, as these methods represent a valuable tool to treat several disorders. A randomized clinical study was the first to report that restoring a healthy gut microbiota is a logical strategy for treating enteric infection (15). The researchers showed the effectiveness of transplanting feces from a healthy patient into patients with recurrent Clostridium difficile infections, which can cause severe diarrhea (15). The composition of the gut microbiota varies during childhood, until the individual reaches adulthood. Differences in this composition are related to colonization; host factors, such as sex and age; genetic factors; and health state. The dynamic state of the microbial ecology is increasingly being associated with an expanding number of disorders. However, the importance of perturbations in the gut microbiota and the subsequent impact on the development of inflammation has only recently been recognized. Therefore, ecological principles such as colonization, succession, resistance to change, competition, and cooperation between community members of the microbiota are beginning to be explored (6). In the post-genomic era, new high-throughput methodologies such as metagenomics, transcriptomics, proteomics, and metabolomics have greatly help the understanding the mechanisms by which the microbiota contributes to host physiology in healthy and diseases. Metagenomic studies of the human gut microbiota, for example, have suggested that low bacterial diversity affects host metabolism and is related with obesity and other diseases $(4,16,17)$. Both microbial diversity and abundance in the gut are important to maintain human health. The microbiota is essential to prevent the attachment, growth, and penetration of pathogenic microorganisms on the gut surface. The intestinal microbiota play an important role in pathogen resistance, both by direct interaction with pathogenic bacteria and by influencing the immune system $(6,18)$. The commensal bacteria that reside in the gut are diverse, and in certain cases, individual species appear to have distinct and opposing roles in the gut immune response. The gut microbiota are essential for the development of the immune system. Certain commensal bacteria appear to preferentially drive T-regulatory lymphocyte development, whereas other bacteria promote Th17 development in the gut (19). Much evidence for how the microbiota shape the immune system comes from studies in GF mice, which completely lack microbiota. Such mice exhibit profound immune defects. The development of Peyer's patches and $\mathrm{B}$ and $\mathrm{T}$ cell compartments in the lamina propria, spleen, and lymph nodes in GF mice is defective (20-22). Consequently, serum immunoglobulin (Ig) G and intestinal IgA levels in GF mice are reduced (23-25). Additionally, many studies in mice and humans indicate that certain inflammatory diseases are associated with an altered microbiota (26-29). Gut microbiota dysbiosis is related to inflammatory disorders, although whether the microbiota change first, leading to disease development, or respond to another factor is unclear; this is a "chicken and egg" problem. A prospective study of children with a high risk of developing asthma suggested that changes in the microbiota occur before disease development (30). It is becoming clear that certain species of gut commensal microbiota are required for the regulation of immune responses and that perturbations in the microbiota could result in a lack of immune regulation, the outgrowth of more pathogenic microbes, and the promotion of inflammation. The microorganism to which the newborn child is exposed during the first years of life will mainly determine the microbial composition of the microbiota in the adult human gut. Indeed strategies to manipulate the microbiota during infancy have been shown to prevent development of allergic and atopic diseases later in adult life (31-33). Thus, the use of probiotics and prebiotics during the early postnatal period has been proposed to intentionally modulate the microbiota composition. In addition, diet and exposure to microbes during pregnancy may influence the metabolic and immunologic profiles of the pregnant uterus and the risk of disease development in the offspring (34). Thus the administration of probiotics and prebiotics during pregnancy has also been proposed. The influence of probiotics and prebiotics on the gut microbiota in both maternal and infant health has been the subject of recent studies $(35,36)$.

The rapid growth of metagenomics strategies is being of great help to understand the role of specific microorganism and the overall diversity of the microbiota in many human diseases. This knowledge can help the development of therapies focused on specific effects of different probiotics and prebiotics on the gut microbiota.

\section{PROBIOTICS AND GUT IMMUNITY}

The idea that bacteria in the gut could play a role as a regulator of health and disease was first proposed by Elie Metchnikoff more than a century ago. Metchnikoff proposed that toxins produced by a putrefactive microorganism in the colon could inhibit the growth of other bacteria. He came across research noting that a certain rural Eastern European population whose staple was large consumption of fermented milk had unusually long lives. Based on this idea, Metchnikoff proposed that "good" lactic acid-producing bacteria were beneficial to the host by reducing the growth and thus the toxic products of other bacteria within the colon, promoting homeostasis (health) in the host (37). He isolated Bacillus bulgaricus and promoted its use as a therapy to maintain homeostasis and prevent aging, thereby popularizing yogurt (37), which formed the foundation for probiotics.

Probiotics are defined by the World Health Organization as "live microorganisms that can provide benefits to human health when administered in adequate amounts, which confer a beneficial health effect on the host" (WHO/2001). Clearly, the conceptual basis of probiotics is well grounded. However, the concept that only "live microorganisms" can induce benefits should be discussed. Microbe-associated molecular pattern (MAMP)elicited signaling has clear effects on epithelial cytoprotection, survival/proliferation pathways, and barrier function $(38,39)$. Several studies have been show that pattern recognition receptors (PRRs), Toll-like receptors, and Nod-like receptors, have crucial roles in maintaining a healthful stable relationship between the host gut and its microbiota $(28,40)$. TLR activation results in the up-regulation of pro-inflammatory mediators that facilitate 
host's immune defense responses. The NLRs are cytoplasmic proteins that regulate inflammatory responses and activation of these PRRs by commensal microbiota has been evolved to contribute to gut homeostasis (41). However, perturbations of PRR-microbiota interactions, in different cells type and gut mucosal compartment, are more likely to promote disease states associated with exacerbated inflammation $(42,43)$.

The benefits that probiotics offer to the host have been shown based on data from animal models and clinical evidence, including effectiveness in the treatment or prevention of acute viral gastroenteritis; post-antibiotic-associated diarrhea; certain pediatric allergic disorders; necrotizing enterocolitis; and inflammatory bowel disease (IBD), such as Crohn's disease and postsurgical pouchitis (Tables 1 and 2). Probiotics have been long reported to aid in the treatment of many dysfunctions of the GI tract, and the mechanisms by which probiotics work have recently been elucidated (Table 3). Clinical trials have shown that the use of probiotics in the prevention of diarrhea can be efficacious especially in newborn and children (44-46). Acute diarrhea is the main symptom of acute gastroenteritis whose most common etiologic agents in children under 1 year are Rotaviruses. There is strong evidence of the clinical benefit of Lactobacillus and Saccharomyces boulardii treatment to decrease the duration of diarrhea (see Table 2) (45). Diarrhea associated with antibiotics administration is also frequent affecting up to $30 \%$ of newborn children (47). Diet supplementation with
Bifidobacterium lactis and Streptococcus thermophilus was shown to reduce the frequency of antibiotic-associated diarrhea (AAD) in infants (48). Increased production of short-chain fatty acids in the colon that stimulates the absorption of sodium by the colonocytes as well as a decrease in intestinal permeability and invasion of pathogenic microorganisms have been proposed to be the major mechanisms by which probiotics reduce diarrheal symptoms $(47,49)$.

For the treatment of IBD, several probiotics have been shown to be efficacious, and especially the commercially available mixture VSL\#3 (a mixture composed of four strains of lactobacilli: Lactobacillus casei, Lactobacillus plantarum, Lactobacillus bulgaricus, and Lactobacillus acidophilus; three strains of bifidobacteria: Bifidobacterium longum, Bifidobacterium breve, and Bifidobacterium infantis; and S. thermophilus) (146-148). The Escherichia coli strain Nissle 1917 has been demonstrated to improve intestinal homeostasis and to minimize the bacterium-induced reduction of the intestinal barrier, thus decreasing the invasion of intestinal epithelial cells by several pathogens. In this review, we highlight the most commonly used probiotic products and the recently described mechanisms in humans (Tables 1-3). Nevertheless, additional research is still needed to elucidate the functional aspects and the detailed mechanisms of action of probiotics and their impact on human health in relation to various diseases. Different probiotic strains exert their beneficial effects via various different

Table 1 | Main manufactured probiotic products commercialized worldwide for human applications.

\begin{tabular}{|c|c|c|c|}
\hline Product name & Microorganism strain(s) & Manufacturer & Type of product \\
\hline Probio-Tec ${ }^{\circledR}$ & Bifidobacterium animalis subsp. lactis BB-12 & $\begin{array}{l}\text { Chr. Hansen A/S, Denmark } \\
\text { (http://www.chr-hansen.com/) }\end{array}$ & Pharmaceutical \\
\hline Culturelle ${ }^{\circledR}$ & Lactobacillus casei subsp. rhamnosus GG & $\begin{array}{l}\text { Valio, Finland } \\
\text { (http://www.valio.com/) }\end{array}$ & Pharmaceutical \\
\hline Enterogermina $^{\circledR}$ & Bacillus clausii & $\begin{array}{l}\text { Sanofi-Aventis, Italy } \\
\text { (http://en.sanofi.com/) }\end{array}$ & Pharmaceutical \\
\hline Ultra-levure ${ }^{\circledR}\left(\right.$ Florastor $\left.^{\circledR}\right)$ & Saccharomyces boulardii & $\begin{array}{l}\text { Biocodex, France } \\
\text { (http://www.biocodex.com/) }\end{array}$ & Pharmaceutical \\
\hline Miyarisan ${ }^{\circledR}$ & Clostridium butyricum MIYAIRI 588 & $\begin{array}{l}\text { Miyarisan Pharmaceutical, Japan } \\
\text { (http://www.miyarisan.com/) }\end{array}$ & Pharmaceutical \\
\hline Mutaflor ${ }^{\circledR}$ & Escherichia coli Nissle 1917 & $\begin{array}{l}\text { Ardeypharm, Germany } \\
\text { (http://www.ardeypharm.de/en/) }\end{array}$ & Pharmaceutical \\
\hline VSL\#3 & $\begin{array}{l}\text { Four strains of Lactobacillus (L. casei, L. plantarum, L. acidophilus, } \\
\text { L. delbrueckii subsp. bulgaricus), three strains of Bifidobacterium } \\
\text { (B. longum, B. breve, B. infantis), and one strain of Streptococcus } \\
\text { salivarius subsp. thermophilus }\end{array}$ & $\begin{array}{l}\text { VSL Pharmaceuticals, Inc., USA } \\
\text { (http://www.sigmatau.com/) }\end{array}$ & Pharmaceutical \\
\hline Actimel ${ }^{\circledR}($ DanActive) & Lactobacillus casei DN-114001 & $\begin{array}{l}\text { Danone, France } \\
\text { (http://www.danone.com/) }\end{array}$ & $\begin{array}{l}\text { Dairy (fermented } \\
\text { milk) }\end{array}$ \\
\hline Activia ${ }^{\circledR}$ & Bifidobacterium animalis DN 173010 & $\begin{array}{l}\text { Danone, France } \\
\text { (http://www.danone.com/) }\end{array}$ & Dairy (yogurt) \\
\hline Yakult $^{\circledR}$ & Lactobacillus casei Shirota & $\begin{array}{l}\text { Yakult Honsha Co., Japan (http: } \\
\text { //www.yakult.co.jp/english/) }\end{array}$ & $\begin{array}{l}\text { Dairy (fermented } \\
\text { milk) }\end{array}$ \\
\hline
\end{tabular}


Table 2 | Main medical/clinical benefits of the major pharmaceutical probiotic products for human purposes.

\begin{tabular}{|c|c|}
\hline Probiotic & Medical/clinical benefits \\
\hline \multirow[t]{6}{*}{ Probio-Tec ${ }^{\circledR a}$} & Relieves constipation (50-54) \\
\hline & Improves fecal properties and microbiota (51) \\
\hline & Has positive effects against acute diarrhea (52) \\
\hline & May have an effect on the gastrointestinal system $(53$ \\
\hline & Reduces antibiotic-associated diarrhea (54) \\
\hline & $\begin{array}{l}\text { Enhances the intestinal antibody response in } \\
\text { formula-fed infants (53) }\end{array}$ \\
\hline \multirow[t]{4}{*}{ Culturelle $^{\circledR}$} & Prevents rotavirus-related diarrhea in children (55-57) \\
\hline & Gastrointestinal disorders in childhood (58-60) \\
\hline & $\begin{array}{l}\text { Reduces the risk of respiratory tract infections in } \\
\text { children (61-63) }\end{array}$ \\
\hline & $\begin{array}{l}\text { Useful in the prevention of atopic dermatitis in } \\
\text { children at high risk of allergy }(64,65)\end{array}$ \\
\hline \multirow[t]{3}{*}{ Enterogermina $^{\circledR}$} & Reduces adverse effects and increases tolerability of \\
\hline & Helicobacter pylori eradication therapy $(66,67)$ \\
\hline & Allergic rhinitis in children (pilot studies) (68) \\
\hline \multirow[t]{8}{*}{ Florastor $^{\circledR}$} & Acute diarrhea $(53,69,70)$ \\
\hline & Recurrent Clostridium difficile infection $(71,72)$ \\
\hline & Antibiotic-associated diarrhea (73-75) \\
\hline & Travelers' diarrhea (76) \\
\hline & Inflammatory bowel disease (77-79) \\
\hline & Irritable bowel syndrome (76) \\
\hline & HIV/AIDS-associated diarrhea $(76,80)$ \\
\hline & Reduction of side effects of $H$. pylori treatment (76, \\
\hline \multirow[t]{2}{*}{ Miyarisan ${ }^{\circledR}$} & Antibiotic-associated diarrhea (83) \\
\hline & Reduction of side effects of $H$. pylori treatment (84) \\
\hline \multirow[t]{4}{*}{ Mutaflor ${ }^{\circledR}$} & Inflammatory bowel disease (85-87) \\
\hline & Acute diarrhea $(88,89)$ \\
\hline & Chronic constipation (90) \\
\hline & Irritable bowel syndrome $(91,92)$ \\
\hline \multirow[t]{3}{*}{ VSL\#3 ${ }^{\circledR}$} & Inflammatory bowel disease $(93,94)$ \\
\hline & Pouchitis $(95,96)$ \\
\hline & Irritable bowel syndrome (97) \\
\hline
\end{tabular}

${ }^{a}$ Many of the positive effects of BB-12 were observed when it was combined with prebiotic formula and/or other probiotic bacteria, especially L. rhamnosus $L G G$, L. acidophilus LA-5, L. casei 431, L. paracasei subsp. paracasei F19, L. bulgaricus $L B Y-27$, and $S$. thermophilus STY-31.

mechanisms and may be synergistic with other microbiota. One probiotic strain may have a different set of properties and clinical effects than another probiotic strain, even if the strains are of the same genus and species. Thus, it is important to note that the efficacy of one probiotic strain does not imply that the other strains will be equally efficacious; rather, further research needs to be performed.

Fukuda and collaborators (149) showed that the probiotic Bifdobacterium protects gnotobiotic mice from death induced by
Table 3 | Main mechanisms of action of the major pharmaceutical probiotic products for human purposes.

\begin{tabular}{|c|c|}
\hline Probiotic & Mechanisms of action \\
\hline \multirow[t]{3}{*}{ BB-12 ${ }^{\circledR}$} & Enhancement of immune response $(98,99)$ \\
\hline & Effect on innate immunity (100) \\
\hline & Modification of microbiota (101) \\
\hline \multirow[t]{8}{*}{ Culturelle $^{\circledR}$} & Prevention of systemic bacteremia (102) \\
\hline & Improvement of intestinal epithelial homeostasis (102) \\
\hline & $\begin{array}{l}\text { Attenuation of local and systemic inflammatory } \\
\text { responses }(102,103)\end{array}$ \\
\hline & Reduction in lipid accumulation (104) \\
\hline & Secretion of anti-inflammatory substances (105) \\
\hline & Local induction of reactive oxygen species (ROS) (106) \\
\hline & Production of bacteriocin (106) \\
\hline & $\begin{array}{l}\text { Interference in bacterium-induced signaling pathways } \\
\text { (107) }\end{array}$ \\
\hline
\end{tabular}

Enterogermina ${ }^{\circledR} \quad$ Improvement of growth performance and immune response (108)

Diminishment of intestinal bacterial overgrowth (109) Antimicrobial and immuno-modulatory activities (110)

Florastor $^{\circledR}$

Antitoxin effects (111-113)

Trophic effects on enterocytes $(113,114)$

Anti-inflammatory effects $(115,116)$

Enhancement of immune response $(117,118)$

Enhancement of levels of disaccharidases (119)

Binding to and elimination of bacterial toxins (120)

Binding to and elimination of pathogenic bacteria (121, 122)

Interference in bacterium-induced signaling pathways $(123,124)$

Actions on bacterial virulence factors (125)

Interference in bacterial motility (126)

Effects on permeability (127)

Miyarisan ${ }^{\circledR}$

Normalization of intestinal microbiota (128)

Reduction in substances with harmful effects on

intestine (129)

Antimicrobial effects (130)

Butyrate production (131)

Mutaflor $^{\circledR}$

Production of colicines (132)

Adhesin associated to colonization (133)

Effects on pathogens, epithelial cells, and immune system (134)

Resistance to colonization by pathogens (135)

Effects on permeability (136)

VSL\#3 ${ }^{\circledR}$

Enhancement of immune response/anti-inflammatory effects (137)

Enhancement of mucosal host defense (138)

Reinforcement of barrier function $(139,140)$

Production of angiogenesis-promoting growth factors (141)

Modulation of microbiota $(142,143)$

Reduces inflammation in Food allergy $(144,145)$ 
enterohemorrhagic E. coli O157:H7. However, the protective and probiotic effects were observed only for certain B. longum subspecies. In contrast, other bifidobacterial strains, such as $B$. longum subsp. infantis JCM $1222 \mathrm{~T}$ (BT) and Bifidobacterium adolescentis JCM 1275T (BA), showed no probiotic effects and failed to prevent the death of mice with $\mathrm{O} 157$ infection. The researchers found that this effect can be attributed, at least in part, to increased production of acetate by the protective bifidobacterial strains, which improves the intestinal defense mediated by epithelial cells (150).

Our research group also investigated certain probiotic properties of different microorganisms (Bifidobacterium animalis var. lactis BB-12, E. coli EMO, L. casei, and the yeast S. boulardii) (118). In vitro and in vivo tests showed that $B$. animalis and E. coli EMO presented better ability to colonize the gastrointestinal tract of GF mice, most likely because the hydrophobic property of the cell walls of these strains increases the strains survival capacity in the gastrointestinal tract of GF mice, without pathological consequences (118). However, S. boulardii, followed by E. coli EMO and B. animalis, induced higher levels of sIgA, and only S. boulardii induced significantly higher levels of IL-10 in the intestine. Thus, we concluded that for a probiotic use, $S$. boulardii had better characteristics in terms of immunomodulation in the intestine (118). An investigation of the mechanism by which different probiotic strains trigger a reaction could help to indicate the best microorganism for therapeutic and prophylactic application in several inflammatory diseases. In addition, it is important to highlight that probiotic properties are not only attributed to bacteria. Previous results from our group showed that treatment with yeast Saccharomyces cerevisiae strain 905 significantly reduced the translocation and dissemination of pathogenic Salmonella typhimurium to all organs in GF and conventional mice after oral infectious challenge (151). The protection conferred by the probiotic against pathogenic bacteria that was observed in this study was most likely due to modulation of both the intestinal and the systemic immunity of mice treated with the probiotic yeast. S. cerevisiae 905 induced a reduction in the levels of pro-inflammatory cytokines and modulated the activation of signaling pathways, such as the mitogen-activated protein kinase (p38 and JNK), NF- $\mathrm{kB}$, and AP-1 pathways, which are involved in the transcriptional activation of pro-inflammatory mediators in the intestine (152). In addition, the probiotic treatment elevated the levels of secretory IgA in the intestine and of IgA and IgM in the serum and the production of the anti-inflammatory cytokine IL10 in the intestine (153). Furthermore, Matins and collaborators demonstrated in vitro and in vivo that probiotic therapies could be useful as adjuvant when treating gastrointestinal diseases. $S$. boulardii, S. cerevisiae UFMG 905, and S. cerevisiae BY474 strains were shown to capture certain pathogenic bacteria on their surface, preventing bacterial adhesion to specific receptors on the intestinal epithelium and subsequent invasion of the host $(151,154)$. Although most of the conditions under which the useful therapeutic application of probiotics were first described were in the gastrointestinal tract, demonstrating regulation of gut immunity, how probiotics could alter host physiology and function in systemic disorders started to be explored once it became apparent that microbial-immunologic relationships with the host may have implications in extra-intestinal systems.
Although most of the effects of probiotics are beneficial, several negative effects should be considered before therapeutic application. The most important concern about probiotic use is the risk of bacteremia, fungemia, and sepsis (155). Thus, use of probiotics in immuno-compromised patients could generate serious health risks. Probiotic research is moving forward due to basic science and clinical trials evaluating the safety and efficacy of probiotics for various medical conditions. However, clinical trials of probiotics still have limitations and further studies about the amount and interval time are still required cause the benefits of probiotic action vary according to that.

\section{PREBIOTICS AND GUT IMMUNITY}

Prebiotics are broadly defined as a food ingredient that is composed of oligosaccharides that are not digestible by the host and that has a beneficial effect on host health through selective stimulation of the growth and/or activity of specific members of the gut microbiota (156). Currently, only inulin and galactooligosaccharides, which are natural food ingredients that are present in certain plants as storage carbohydrates, fulfill all of the criteria for prebiotic classification. Although the previous definition of prebiotics is only applicable to selectively fermented food components, and although much of the prebiotic literature focuses on non-digestible oligosaccharides, most dietary fibers that are fermentable carbohydrates could be considered as prebiotics as well. We hypothesize that any type of dietary or food supplement that could promote the growth of beneficial bacteria and consequently promote homeostasis in the gut and good health could be considered as a prebiotic, even though the supplement may not meet the required criteria.

Fiber carbohydrates (including cellulose, pectin, gums, betaglucan, and lignin) are not digested in the upper gastrointestinal tract because the host does not have the enzymatic capability to degrade these carbohydrates (157). However, these substances are thought to be selectively ferment by residential bacteria into SCFAs, and particularly acetate, propionate, butyrate, and lactate, once in the colon (158). The vast majority of the bacteria in the colon are strict anaerobes that derive energy from fermentation. The gut microbiota can ferment fiber due to their expression of several enzymes and transport proteins.

Diet alone has the strongest and most direct effects on gut microbial colonization because bacteria have different preferences for different energy sources. Thus, diet is closely related to the species present in the gut microbiota $(156,159)$. The profile of dominant species in the human gut microbiota can potentially be modified by dietary intake, with consequences for health. The two most abundant phyla found in most healthy individuals are the Bacteroidetes and Firmicutes $(160,161)$. Dietary fibers can act as effective prebiotics by inducing major shifts in gut microbial composition and directly affecting the mucosal immune system, resulting in an improvement in enteric inflammatory disorders and the systemic immune response (see Table 4).

The anti-inflammatory effects of fiber are likely to be driven by SCFAs. SCFAs have been known to be beneficial for bowel health for many decades. A decrease in "healthy" microbiota and SCFAs is characteristic of patients with IBD, which is most likely due to a reduction in anaerobic bacteria (182). Nevertheless, the delivery 
Table 4 | Main benefits of the major prebiotics and potential mechanisms of action.

\begin{tabular}{|c|c|c|c|}
\hline Prebiotic & Medical/clinical benefits & Mechanisms of action & Reference \\
\hline \multirow[t]{7}{*}{ Inulin } & Crohn's disease & Enhancement of immune response & Emilia et al. (162) \\
\hline & Colitis & Effect on innate immunity & Macfarlane et al. (163), \\
\hline & & & Ramirez-Farias et al. (164) \\
\hline & Obesity & Modification of microbiota and increase in Bifidobacteria & Hopping et al. (165) \\
\hline & Diabetes type 2 & & Costabile et al. (166) \\
\hline & Colon cancer & & Ramnani et al. (167) \\
\hline & Constipation & & \\
\hline \multirow{6}{*}{$\begin{array}{l}\text { FOS (Fructo- } \\
\text { oligosaccharides) }\end{array}$} & Crohn's disease & Increase in Bifidobacteria & Scholtens et al. (168) \\
\hline & Colitis, & Decrease in colon $\mathrm{pH}$ & Benjamin et al. (169) \\
\hline & Obesity & Reduction in lipid accumulation & de Luis et al. (170) \\
\hline & Constipation & Secretion of anti-inflammatory substances & Cummings et al. (171) \\
\hline & Travelers' diarrhea & Local induction of reactive oxygen species (ROS) & Arslanoglu et al. (172) \\
\hline & Colon cancer & & Boutron-Ruault et al. (173) \\
\hline \multirow{3}{*}{$\begin{array}{l}\text { GOS (Galacto- } \\
\text { oligosaccharides) }\end{array}$} & Crohn's disease & Improvement of growth performance and immune responses & Saavedra and Tschernia (174) \\
\hline & Colitis & Diminishment of intestinal bacterial overgrowth & Macfarlane et al. (163) \\
\hline & Obesity & & Drakoularakou et al. (175) \\
\hline \multirow{7}{*}{$\begin{array}{l}\text { Soluble fiber } \\
\text { (Guar gum, } \\
\text { pectin) }\end{array}$} & Crohn's disease & Enhancement of short-chain fatty acid production, and mainly acetate & Peng et al. (176) \\
\hline & Celiac disease & Normalization of intestinal microbiota & Slavin (177) \\
\hline & Colitis & Effects on epithelial permeability & Chen et al. (178) \\
\hline & Colon cancer & Trophic effects on enterocytes & Hu et al. (179) \\
\hline & Metabolic syndrome & Anti-inflammatory effects & Cao et al. (180) \\
\hline & Arthritis & Enhancement of immune response & Slavin (181) \\
\hline & Cardiovascular diseases & Reduction of blood pressure and reduction of LDL serum concentrations & \\
\hline
\end{tabular}

of SCFAs has been shown to be successful and effective in reducing colitis $(183,184)$ and other colonic inflammatory disorders (185). One of the most studied SCFAs is butyrate. Butyrate is the major energy source of colonic epithelial cells affects the proliferation and barrier function of the colonic epithelium and reduces oxidative DNA damage $(186,187)$. This energy source is transported into cells via monocarboxylate transporters, such as MCT-1107 (188). Butyrate has been shown to reduce the incidence of colon cancer by inhibiting histone deacetylases (HDACs), which affects binding to DNA and thereby transcriptional activity (189). Butyrate, which is more highly produced on a resistant starch, soluble fiber, and inulin diet, was also associated with increased percentages of T-regulatory cells (Treg) and reduced production of IFN- $\gamma$, suggesting a down-regulation of inflammation, in an experimental model of IBD (190). High levels of butyrate induced the activation of a nuclear transcription factor and peroxisome proliferator activator receptor $\gamma(\operatorname{PPAR} \gamma)(191,192)$. PPAR $\gamma$ was first shown to be efficacious in suppressing intestinal inflammation in experimental models of colitis (193). In addition, the activation of PPAR $\gamma$ was shown to reduce pro-inflammatory pathways, such as the STAT, AP-1, and NF- $\kappa$ B pathways, in gut inflammation.

Although most studies on SCFAs have focused on butyrate, acetate is the most abundantly produced SCFA in the colon. Recently, our group and others have shown the anti-inflammatory effects of acetate on the inflammatory response and have started to explore the mechanisms $(183,194,195)$. The receptors GPR41 (Ffar1), GPR109A, and GPR43 (Ffar2) were identified as receptors for the SCFAs butyrate, propionate, and acetate (196). GPR41 is primarily expressed by adipose tissue and is also present at very low levels in peripheral blood mononuclear cells (PBMCs). In contrast, GPR43 expression is nearly exclusive to the immune system and is particularly high on polymorphonuclear cells (eosinophils and neutrophils) (183). Our group previously showed that mice that lack the Gpr43 gene have increased inflammation and a poor ability to resolve inflammation because their immune cells cannot bind to SCFAs. Gpr $43^{-1-}$ mice were more susceptible to IBD (183). However, treatment with acetate improved the clinical and inflammatory responses in wt mice, and these effects were dependent on acetate/Gpr43 activation. Interestingly, acetate is largely produced in the colon but reaches a high concentration in the blood, so we could observe systemic anti-inflammatory effects of this SCFA in other diseases, such as asthma and arthritis. More recently, the effect of SCFAs on the specific induction of Foxp3+ IL-10-producing Tregs and the consequent protection of mice against colitis was shown to occur in a GPR43-dependent manner (195).

The molecular mechanism that might explain how a diet enriched in fiber affects the immune system is starting to be elucidated. In addition to increasing the production of SCFAs, such as acetate, propionate, and butyrate, other protective mechanisms of prebiotic activity have been proposed. Prebiotics can also provide resistance to colonization by pathogenic bacteria by inhibiting the adherence of pathogens to the gut epithelium. Other health effects of prebiotics, such as prevention of diarrhea or constipation, 
positive effects on lipid metabolism, and stimulation of mineral adsorption, are indirectly mediated by regulation of the intestinal microbiota (197).

Our group has demonstrated that another marketed nutritional supplement that has the potential to reduce gastrointestinal inflammation is the marine alga Lithothamnium muelleri. Although we still do not know the mechanisms by which L. muelleri induces protection in the gut, L. muelleri is known to be a good source of polysaccharides and calcium carbonate, which is largely formed in its cell walls. Others species of Lithothamnium sp. were shown to be useful as dietary supplements as well and were efficient in chemoprevention of colon polyp formation in animal models (198). These data on the provision of polysaccharides suggest that the use of marine algae as a dietary supplement for anti-inflammatory purposes may provide a novel approach to prebiotics.

Over the past decades, our diet has changed greatly. The consumption of fiber has decreased, accompanied by an increase in high-fat, high-calorie, and processed food. At the same time, the number of people affected by inflammatory diseases has increased. It seems reasonable to suggest that a change in environmental factors, such as diet, in Western societies could be altering our microbiota and therefore our susceptibility to inflammatory disease. In this context, restoring a healthy gut microbiota by external dietary intervention is a logical strategy. Furthermore, given the strong immuno-modulatory function of SCFAs, the production of microbe-derived metabolites using prebiotics is being explored as a promising avenue for prophylactic and therapeutic intervention in gut inflammation. In this way, studies on prebiotics have multiplied in search of a promising new therapy to treat disease and adjuvant therapy along with probiotics, forming symbiotics.

\section{PERSPECTIVE ON AND FUTURE OF SYMBIOTIC THERAPIES}

Prebiotics could be administered along with live bacteria (probiotics) that are most able to exploit that energy source to improve the health benefits to the host. The synergistic combinations of probiotics and prebiotics are called symbiotics. The possible health benefits of prebiotics, probiotics, and symbiotics are now being explored in many situations, facilitated by their safety and ease of use. It is important to note that the benefits of regulating the gut microbiota to induce intestinal homeostasis largely extend to other systems in the host. A substantial literature is accumulating on prebiotics and probiotics in several chronic diseases, such as obesity, arthritis, diabetes, cancers, asthma, alcoholism, and cardiovascular diseases, and their effects on host behavior.

The treatment strategies demonstrated by our group using a probiotic $S$. cerevisiae strain enriched with organic selenium in mice and rats with rheumatoid arthritis (RA) resulted in a decrease in several inflammatory parameters, such as infiltration by inflammatory cells, pro-inflammatory cytokine and chemokine production, paw edema, and hypernociception. This inactive yeast enriched with organic Se is a product called Selemax, and we revealed the role of selenium in the amelioration of inflammation associated with the joints. As an antioxidant, selenium plays a vital role in minimizing free-radical activity and is known to strongly influence immune responses. The association of organic selenium and the yeast $S$. cerevisiae (which can transform inorganic Se into organic Se) is a good example of a symbiotic product serving as a promising therapy. Given the effects of prebiotics and probiotics on the gut microbiota, yielding a healthier microbiota and immuno-modulatory properties, and the synergism between these agents, the use of symbiotics to treat many disorders is potentially of great interest. Dissecting the mechanisms by which probiotics, prebiotics, and symbiotics confer benefit on the host will lead to better utilization in treating human diseases involving the immune system.

\section{CONCLUSION}

Despite recent advances in our understanding of the structure and function of microbial community, we are still only beginning to discover the mechanisms by which changes in the microbiota can affect several disorders. A major challenge to understanding the functional impact of microbial communities on health and disease is the heterogeneity of these communities and the fact that their composition can be influenced by various factors, including host genetics, nutrition, antibiotic treatment, infection, and sequential microbial colonization in the neonatal period. Nevertheless, we have learned that certain species of bacteria can have large effects on the gut immune system and that the balance of these influences is important to the maintenance of homeostasis and the development of novel disease treatment and management strategies. In this context, prebiotics and/or probiotics are a powerful strategy for manipulating the microbial composition and immune responses of the host.

\section{ACKNOWLEDGMENTS}

This study was supported by $\mathrm{CNPq}$ (Conselho Nacional de Desenvolvimento Científico e Tecnológico, Brazil), FAPEMIG (Fundação de Amparo á Pesquisa do Estado de Minas Gerais, Brazil), The program "Instituto Nacional de Ciência e Tecnologia" (INCT in Dengue), and from the European Community's Seventh Framework Program [FP7-2007-2013] under grant agreement $\mathrm{n}^{\circ}$ HEALTH-F4-2011-281608.

\section{REFERENCES}

1. Pabst R, Russell MW, Brandtzaeg P. Tissue distribution of lymphocytes and plasma cells and the role of the gut. Trends Immunol (2008) 29:206-8. doi:10.1016/j.it.2008.02.006

2. Hooper LV, Macpherson AJ. Immune adaptations that maintain homeostasis with the intestinal microbiota. Nat Rev Immunol (2010) 10:159-69. doi:10.1038/nri2710

3. Hooper LV, Littman DR, Macpherson AJ. Interactions between the microbiota and the immune system. Science (2012) 336:1268-73. doi:10.1126/science. 1223490

4. Qin J, Li R, Raes J, Arumugam M, Burgdorf KS, Manichanh C, et al. A human gut microbial gene catalogue established by metagenomic sequencing. Nature (2010) 464:59-65. doi:10.1038/nature08821

5. Louis $\mathrm{P}$, O’Byrne CP. Life in the gut: microbial responses to stress in the gastrointestinal tract. Sci Prog (2010) 93:7-36. doi:10.3184/ 003685009X12605525292307

6. Kamada N, Chen GY, Inohara N, Nunez G. Control of pathogens and pathobionts by the gut microbiota. Nat Immunol (2013) 14:685-90. doi:10.1038/ni. 2608ni.2608

7. Artis D. Epithelial-cell recognition of commensal bacteria and maintenance of immune homeostasis in the gut. Nat Rev Immunol (2008) 8:411-20. doi:10.1038/nri2316 
8. Wells JM, Rossi O, Meijerink M, van Baarlen P. Epithelial crosstalk at the microbiota-mucosal interface. Proc Natl Acad Sci U S A (2011) 108(Suppl 1):4607-14. doi:10.1073/pnas.10000921071000092107

9. Duerr CU, Hornef MW. The mammalian intestinal epithelium as integral player in the establishment and maintenance of host-microbial homeostasis. Semin Immunol (2012) 24:25-35. doi:10.1016/j.smim.2011.11.002

10. Henao-Mejia J, Elinav E, Jin C, Hao L, Mehal WZ, Strowig T, et al. Inflammasome-mediated dysbiosis regulates progression of NAFLD and obesity. Nature (2012) 482:179-85. doi:10.1038/nature10809nature10809

11. Vujkovic-Cvijin I, Dunham RM, Iwai S, Maher MC, Albright RG, Broadhurst MJ, et al. Dysbiosis of the gut microbiota is associated with HIV disease progression and tryptophan catabolism. Sci Transl Med (2013) 5:193ra191. doi:10.1126/scitranslmed.30064385/193/193ra91

12. Smith MI, Yatsunenko T, Manary MJ, Trehan I, Mkakosya R, Cheng J, et al. Gut microbiomes of Malawian twin pairs discordant for kwashiorkor. Science (2013) 339:548-54. doi:10.1126/science. 1229000

13. Turnbaugh PJ, Gordon JI. The core gut microbiome, energy balance and obesity. J Physiol (2009) 587:4153-8. doi:10.1113/jphysiol.2009.174136

14. Turnbaugh PJ, Hamady M, Yatsunenko T, Cantarel BL, Duncan A, Ley RE, et al. A core gut microbiome in obese and lean twins. Nature (2009) 457:480-4. doi:10.1038/nature 07540

15. van Nood E, Vrieze A, Nieuwdorp M, Fuentes S, Zoetendal EG, De Vos WM, et al. Duodenal infusion of donor feces for recurrent Clostridium difficile. N Engl J Med (2013) 368:407-15. doi:10.1056/NEJMoa1205037

16. Blottiere HM, De Vos WM, Ehrlich SD, Dore J. Human intestinal metagenomics: state of the art and future. Curr Opin Microbiol (2013) 16:232-9. doi:10.1016/j.mib.2013.06.006S1369-5

17. Le Chatelier E, Nielsen T, Qin J, Prifti E, Hildebrand F, Falony G, et al. Richness of human gut microbiome correlates with metabolic markers. Nature (2013) 500:541-6. doi:10.1038/nature12506

18. Tlaskalova-Hogenova H, Stepankova R, Hudcovic T, Tuckova L, Cukrowska B, Lodinova-Zadnikova R, et al. Commensal bacteria (normal microflora), mucosal immunity and chronic inflammatory and autoimmune diseases. Immunol Lett (2004) 93:97-108. doi:10.1016/j.imlet.2004.02.005

19. Kamada N, Nunez G. Role of the gut microbiota in the development and function of lymphoid cells. J Immunol (2013) 190:1389-95. doi:10.4049/jimmunol. 1203100190/4/1389

20. Gordon HA. Morphological and physiological characterization of germfree life. Ann N Y Acad Sci (1959) 78:208-20. doi:10.1111/j.1749-6632.1959.tb53104.x

21. Glaister JR. Factors affecting the lymphoid cells in the small intestinal epithelium of the mouse. Int Arch Allergy Appl Immunol (1973) 45:719-30. doi:10.1159/000231071

22. Cebra JJ, Periwal SB, Lee G, Lee F, Shroff KE. Development and maintenance of the gut-associated lymphoid tissue (GALT): the roles of enteric bacteria and viruses. Dev Immunol (1998) 6:13-8. doi:10.1155/1998/68382

23. Wagner M, Wostmann BS. Serum protein fractions and antibody studies in gnotobiotic animals reared germfree or monocontaminated. Ann N Y Acad Sci (1961) 94:210-7. doi:10.1111/j.1749-6632.1961.tb35542.x

24. Sell S, Fahey JL. Relationship between gamma-globulin metabolism and low serum gamma-globulin in germfree mice. J Immunol (1964) 93:81-7.

25. Moreau MC, Ducluzeau R, Guy-Grand D, Muller MC. Increase in the population of duodenal immunoglobulin A plasmocytes in axenic mice associated with different living or dead bacterial strains of intestinal origin. Infect Immun (1978) 21:532-9.

26. Seksik P, Rigottier-Gois L, Gramet G, Sutren M, Pochart P, Marteau P, et al. Alterations of the dominant faecal bacterial groups in patients with Crohn's disease of the colon. Gut (2003) 52:237-42. doi:10.1136/gut.52.2.237

27. Jeffery IB, O’Toole PW, Ohman L, Claesson MJ, Deane J, Quigley EM, et al. An irritable bowel syndrome subtype defined by species-specific alterations in faecal microbiota. Gut (2012) 61:997-1006. doi:10.1136/gutjnl-2011-301501

28. Kamada N, Seo SU, Chen GY, Nunez G. Role of the gut microbiota in immunity and inflammatory disease. Nat Rev Immunol (2013) 13:321-35. doi:10.1038/nri3430

29. Simren M, Barbara G, Flint HJ, Spiegel BM, Spiller RC, Vanner S, et al. Intestinal microbiota in functional bowel disorders: a Rome foundation report. Gut (2013) 62:159-76. doi:10.1136/gutjnl-2012-302167

30. Bisgaard H, Li N, Bonnelykke K, Chawes BL, Skov T, Paludan-Muller G, et al. Reduced diversity of the intestinal microbiota during infancy is associated with increased risk of allergic disease at school age. J Allergy Clin Immunol (2011) 128(646-652):e641-5. doi:10.1016/j.jaci.2011.04.060

31. Kalliomaki M, Isolauri E. Pandemic of atopic diseases - a lack of microbial exposure in early infancy? Curr Drug Targets Infect Disord (2002) 2:193-9. doi:10.2174/1568005023342452

32. Rautava S, Kalliomaki M, Isolauri E. Probiotics during pregnancy and breastfeeding might confer immunomodulatory protection against atopic disease in the infant. J Allergy Clin Immunol (2002) 109:119-21. doi:10.1067/mai.2002. 120273

33. Kukkonen K, Savilahti E, Haahtela T, Juntunen-Backman K, Korpela R, Poussa $\mathrm{T}$, et al. Probiotics and prebiotic galacto-oligosaccharides in the prevention of allergic diseases: a randomized, double-blind, placebo-controlled trial. JAllergy Clin Immunol (2007) 119:192-8. doi:10.1016/j.jaci.2006.09.009

34. Barker DJ. The origins of the developmental origins theory. J Intern Med (2007) 261:412-7. doi:10.1111/j.1365-2796.2007.01809.x

35. Boyle RJ, Mah LJ, Chen A, Kivivuori S, Robins-Browne RM, Tang ML. Effects of Lactobacillus GG treatment during pregnancy on the development of fetal antigen-specific immune responses. Clin Exp Allergy (2008) 38:1882-90. doi:10.1111/j.1365-2222.2008.03100.x

36. Laitinen K, Poussa T, Isolauri E. Probiotics and dietary counselling contribute to glucose regulation during and after pregnancy: a randomised controlled trial. Br J Nutr (2009) 101:1679-87. doi:10.1017/S0007114508111461

37. Podolsky S. Cultural divergence: Elie Metchnikoff's Bacillus bulgaricus therapy and his underlying concept of health. Bull Hist Med (1998) 72:1-27. doi:10.1353/bhm.1998.0056

38. Rakoff-Nahoum S, Paglino J, Eslami-Varzaneh F, Edberg S, Medzhitov R. Recognition of commensal microflora by toll-like receptors is required for intestinal homeostasis. Cell (2004) 118:229-41. doi:10.1016/j.cell.2004.07.002

39. Eberl G, Boneca IG. Bacteria and MAMP-induced morphogenesis of the immune system. Curr Opin Immunol (2010) 22:448-54. doi:10.1016/j.coi.2010. 06.002

40. Abreu MT. Toll-like receptor signalling in the intestinal epithelium: how bacterial recognition shapes intestinal function. Nat Rev Immunol (2010) 10:131-44. doi:10.1038/nri2707nri2707

41. Yeretssian G. Effector functions of NLRs in the intestine: innate sensing, cell death, and disease. Immunol Res (2012) 54:25-36. doi:10.1007/s12026-0128317-3

42. Lavelle EC, Murphy C, O'Neill LA, Creagh EM. The role of TLRs, NLRs, and RLRs in mucosal innate immunity and homeostasis. Mucosal Immunol (2010) 3:17-28. doi:10.1038/mi.2009.124

43. Maynard CL, Elson CO, Hatton RD, Weaver CT. Reciprocal interactions of the intestinal microbiota and immune system. Nature (2012) 489:231-41. doi:10.1038/nature11551

44. Allen SJ, Okoko B, Martinez E, Gregorio G, Dans LF. Probiotics for treating infectious diarrhoea. Cochrane Database Syst Rev (2004) 2:CD003048. doi:10.1002/14651858.CD003048.pub2

45. Guandalini S. Probiotics for prevention and treatment of diarrhea. J Clin Gastroenterol (2011) 45(Suppl):S149-53. doi:10.1097/MCG.0b013e3182257e98

46. Szajewska H, Wanke M, Patro B. Meta-analysis: the effects of Lactobacillus rhamnosus GG supplementation for the prevention of healthcare-associated diarrhoea in children. Aliment Pharmacol Ther (2011) 34:1079-87. doi:10. 1111/j.1365-2036.2011.04837.x

47. Szajewska H, Mrukowicz J. Meta-analysis: non-pathogenic yeast Saccharomyces boulardii in the prevention of antibiotic-associated diarrhoea. Aliment Pharmacol Ther (2005) 22:365-72. doi:10.1111/j.1365-2036.2005.02624.x

48. Correa NB, Peret Filho LA, Penna FJ, Lima FM, Nicoli JR. A randomized formula controlled trial of Bifidobacterium lactis and Streptococcus thermophilus for prevention of antibiotic-associated diarrhea in infants. J Clin Gastroenterol (2005) 39:385-9. doi:10.1097/01.mcg.0000159217.47419.5b

49. Morais MB, Jacob CM. The role of probiotics and prebiotics in pediatric practice. J Pediatr (Rio J) (2006) 82:S189-97. doi:10.2223/JPED.1559

50. Wenus C, Goll R, Loken EB, Biong AS, Halvorsen DS, Florholmen J. Prevention of antibiotic-associated diarrhoea by a fermented probiotic milk drink. Eur J Clin Nutr (2008) 62:299-301. doi:10.1038/sj.ejcn.1602718

51. Savard P, Lamarche B, Paradis ME, Thiboutot H, Laurin E, Roy D. Impact of Bifidobacterium animalis subsp. lactis BB-12 and, Lactobacillus acidophilus LA5-containing yoghurt, on fecal bacterial counts of healthy adults. Int J Food Microbiol (2011) 149:50-7. doi:10.1016/j.ijfoodmicro.2010.12.026 
52. Taipale T, Pienihakkinen K, Isolauri E, Larsen C, Brockmann E, Alanen P, et al. Bifidobacterium animalis subsp. lactis BB-12 in reducing the risk of infections in infancy. Br J Nutr (2011) 105:409-16. doi:10.1017/S0007114510003685

53. Dinleyici EC, Eren M, Ozen M, Yargic ZA, Vandenplas Y. Effectiveness and safety of Saccharomyces boulardii for acute infectious diarrhea. Expert Opin Biol Ther (2012) 12:395-410. doi:10.1517/14712598.2012.664129

54. Holscher HD, Czerkies LA, Cekola P, Litov R, Benbow M, Santema S, et al. Bifidobacterium lactis $\mathrm{Bb} 12$ enhances intestinal antibody response in formula-fed infants: a randomized, double-blind, controlled trial. JPEN J Parenter Enteral Nutr (2012) 36:106S-17S. doi:10.1177/014860711143081736/1_suppl/106S

55. Guandalini S, Pensabene L, Zikri MA, Dias JA, Casali LG, Hoekstra H, et al. Lactobacillus GG administered in oral rehydration solution to children with acute diarrhea: a multicenter European trial. J Pediatr Gastroenterol Nutr (2000) 30:54-60. doi:10.1097/00005176-200001000-00018

56. Canani RB, Cirillo P, Terrin G, Cesarano L, Spagnuolo MI, De Vincenzo A, et al. Probiotics for treatment of acute diarrhoea in children: randomised clinical trial of five different preparations. BMJ (2007) 335:340. doi:10.1136/bmj. 39272.581736 .55

57. Szajewska H, Skorka A, Ruszczynski M, Gieruszczak-Bialek D. Meta-analysis: Lactobacillus GG for treating acute gastroenteritis in children - updated analysis of randomised controlled trials. Aliment Pharmacol Ther (2013) 38(5):467-76. doi:10.1111/apt.12403

58. Vanderhoof JA, Whitney DB, Antonson DL, Hanner TL, Lupo JV, Young RJ. Lactobacillus GG in the prevention of antibiotic-associated diarrhea in children. J Pediatr (1999) 135:564-8. doi:10.1016/S0022-3476(99)70053-3

59. Horvath A, Dziechciarz P, Szajewska H. Meta-analysis: Lactobacillus rhamnosus GG for abdominal pain-related functional gastrointestinal disorders in childhood. Aliment Pharmacol Ther (2011) 33:1302-10. doi:10.1111/j.1365-2036. 2011.04665.x

60. Piescik-Lech M, Urbanska M, Szajewska H. Lactobacillus GG (LGG) and smectite versus LGG alone for acute gastroenteritis: a double-blind, randomized controlled trial. Eur J Pediatr (2013) 172:247-53. doi:10.1007/s00431-0121878-2

61. Hatakka K, Savilahti E, Ponka A, Meurman JH, Poussa T, Nase L, et al. Effect of long term consumption of probiotic milk on infections in children attending day care centres: double blind, randomised trial. BMJ (2001) 322:1327. doi:10.1136/bmj.322.7298.1327

62. Hojsak I, Snovak N, Abdovic S, Szajewska H, Misak Z, Kolacek S. Lactobacillus GG in the prevention of gastrointestinal and respiratory tract infections in children who attend day care centers: a randomized, double-blind, placebocontrolled trial. Clin Nutr (2010) 29:312-6. doi:10.1016/j.clnu.2009.09.008

63. Liu S, Hu P, Du X, Zhou T, Pei X. Lactobacillus rhamnosus GG supplementation for preventing respiratory infections in children: a meta-analysis of randomized, placebo-controlled trials. Indian Pediatr (2013) 50:377-81. doi:10.1007/s13312-013-0123-z

64. Kalliomaki M, Salminen S, Arvilommi H, Kero P, Koskinen P, Isolauri E. Probiotics in primary prevention of atopic disease: a randomised placebo-controlled trial. Lancet (2001) 357:1076-9. doi:10.1016/S0140-6736(00)04259-8

65. Kalliomaki M, Salminen S, Poussa T, Isolauri E. Probiotics during the first 7 years of life: a cumulative risk reduction of eczema in a randomized, placebocontrolled trial. JAllergy Clin Immunol (2007) 119:1019-21. doi:10.1016/j.jaci. 2006.12.608

66. Nista EC, Candelli M, Cremonini F, Cazzato IA, Zocco MA, Franceschi F, et al. Bacillus clausii therapy to reduce side-effects of anti-helicobacter pylori treatment: randomized, double-blind, placebo controlled trial. Aliment Pharmacol Ther (2004) 20:1181-8. doi:10.1111/j.1365-2036.2004.02274.x

67. Wilhelm SM, Johnson JL, Kale-Pradhan PB. Treating bugs with bugs: the role of probiotics as adjunctive therapy for Helicobacter pylori. Ann Pharmacother (2011) 45:960-6. doi:10.1345/aph.1Q104

68. Marseglia GL, Tosca M, Cirillo I, Licari A, Leone M, Marseglia A, et al. Efficacy of Bacillus clausii spores in the prevention of recurrent respiratory infections in children: a pilot study. Ther Clin Risk Manag (2007) 3:13-7. doi:10.2147/tcrm.2007.3.1.13

69. Szajewska H, Skorka A, Dylag M. Meta-analysis: Saccharomyces boulardii for treating acute diarrhoea in children. Aliment Pharmacol Ther (2007) 25:257-64. doi:10.1111/j.1365-2036.2006.03202.x

70. Piescik-Lech M, Shamir R, Guarino A, Szajewska H. Review article: the management of acute gastroenteritis in children. Aliment Pharmacol Ther (2013) 37:289-303. doi:10.1111/apt.12163
71. McFarland LV. Meta-analysis of probiotics for the prevention of antibiotic associated diarrhea and the treatment of Clostridium difficile disease. Am J Gastroenterol (2006) 101:812-22. doi:10.1111/j.1572-0241.2006.00465.x

72. Segarra-Newnham M. Probiotics for Clostridium difficile-associated diarrhea: focus on Lactobacillus rhamnosus GG and Saccharomyces boulardii. Ann Pharmacother (2007) 41:1212-21. doi:10.1345/aph.1K110

73. Szajewska H, Ruszczynski M, Radzikowski A. Probiotics in the prevention of antibiotic-associated diarrhea in children: a meta-analysis of randomized controlled trials. J Pediatr (2006) 149:367-72. doi:10.1016/j.jpeds.2006.04.053

74. Doron SI, Hibberd PL, Gorbach SL. Probiotics for prevention of antibioticassociated diarrhea. J Clin Gastroenterol (2008) 42(Suppl 2):S58-63. doi:10. 1097/MCG.0b013e3181618ab7

75. Johnston BC, Goldenberg JZ, Vandvik PO, Sun X, Guyatt GH. Probiotics for the prevention of pediatric antibiotic-associated diarrhea. Cochrane Database Syst Rev (2011) 11:CD004827. doi:10.1002/14651858.CD004827.pub3

76. McFarland LV. Systematic review and meta-analysis of Saccharomyces boulardii in adult patients. World J Gastroenterol (2010) 16:2202-22. doi:10.3748/wjg. v16.i18.2202

77. Guslandi M, Mezzi G, Sorghi M, Testoni PA. Saccharomyces boulardii in maintenance treatment of Crohn's disease. Dig Dis Sci (2000) 45:1462-4. doi:10.1023/A:1005588911207

78. Guslandi M, Giollo P, Testoni PA. A pilot trial of Saccharomyces boulardii in ulcerative colitis. Eur J Gastroenterol Hepatol (2003) 15:697-8. doi:10.1097/01. meg.0000059138.68845.06

79. Guslandi M. Saccharomyces boulardii plus rifaximin in mesalamine-intolerant ulcerative colitis. J Clin Gastroenterol (2010) 44:385. doi:10.1097/MCG. 0b013e3181cb4233

80. Saint-Marc T, Rossello-Prats L, Touraine JL. [Efficacy of Saccharomyces boulardii in the treatment of diarrhea in AIDS]. Ann Med Interne (Paris) (1991) 142:64-5.

81. Cremonini F, Di Caro S, Covino M, Armuzzi A, Gabrielli M, Santarelli L, et al. Effect of different probiotic preparations on anti-helicobacter pylori therapyrelated side effects: a parallel group, triple blind, placebo-controlled study. Am J Gastroenterol (2002) 97:2744-9. doi:10.1111/j.1572-0241.2002.07063.x

82. Szajewska H, Horvath A, Piwowarczyk A. Meta-analysis: the effects of Saccharomyces boulardii supplementation on Helicobacter pylori eradication rates and side effects during treatment. Aliment Pharmacol Ther (2010) 32:1069-79. doi:10.1111/j.1365-2036.2010.04457.x

83. Seki H, Shiohara M, Matsumura T, Miyagawa N, Tanaka M, Komiyama A, et al. Prevention of antibiotic-associated diarrhea in children by Clostridium butyricum MIYAIRI. Pediatr Int (2003) 45:86-90. doi:10.1046/j.1442-200X. 2003.01671.x

84. Shimbo I, Yamaguchi T, Odaka T, Nakajima K, Koide A, Koyama H, et al. Effect of Clostridium butyricum on fecal flora in Helicobacter pylori eradication therapy. World J Gastroenterol (2005) 11:7520-4.

85. Kruis W, Fric P, Pokrotnieks J, Lukas M, Fixa B, Kascak M, et al. Maintaining remission of ulcerative colitis with the probiotic Escherichia coli Nissle 1917 is as effective as with standard mesalazine. Gut (2004) 53:1617-23. doi:10.1136/gut.2003.037747

86. Henker J, Muller S, Laass MW, Schreiner A, Schulze J. Probiotic Escherichia coli Nissle 1917 (EcN) for successful remission maintenance of ulcerative colitis in children and adolescents: an open-label pilot study. Z Gastroenterol (2008) 46:874-5. doi:10.1055/s-2008-1027463

87. Matthes H, Krummenerl T, Giensch M, Wolff C, Schulze J. Clinical trial: probiotic treatment of acute distal ulcerative colitis with rectally administered Escherichia coli Nissle 1917 (EcN). BMC Complement Altern Med (2010) 10:13. doi:10.1186/1472-6882-10-13

88. Henker J, Laass M, Blokhin BM, Bolbot YK, Maydannik VG, Elze M, et al. The probiotic Escherichia coli strain Nissle 1917 (EcN) stops acute diarrhoea in infants and toddlers. Eur J Pediatr (2007) 166:311-8. doi:10.1007/s00431-0070419-x

89. Henker J, Laass MW, Blokhin BM, Maydannik VG, Bolbot YK, Elze M, et al. Probiotic Escherichia coli Nissle 1917 versus placebo for treating diarrhea of greater than 4 days duration in infants and toddlers. Pediatr Infect Dis J (2008) 27:494-9. doi:10.1097/INF.0b013e318169034c

90. Mollenbrink M, Bruckschen E. [Treatment of chronic constipation with physiologic Escherichia coli bacteria. Results of a clinical study of the effectiveness and tolerance of microbiological therapy with the E. coli Nissle 1917 strain (Mutaflor)]. Med Klin (Munich) (1994) 89:587-93. 
91. Plassmann D, Schulte-Witte H. [Treatment of irritable bowel syndrome with Escherichia coli strain Nissle 1917 (EcN): a retrospective survey]. Med Klin (Munich) (2007) 102:888-92. doi:10.1007/s00063-007-1116-2

92. Kruis W, Chrubasik S, Boehm S, Stange C, Schulze J. A double-blind placebocontrolled trial to study therapeutic effects of probiotic Escherichia coli Nissle 1917 in subgroups of patients with irritable bowel syndrome. Int J Colorectal Dis (2012) 27:467-74. doi:10.1007/s00384-011-1363-9

93. Chapman TM, Plosker GL, Figgitt DP. VSL\#3 probiotic mixture: a review of its use in chronic inflammatory bowel diseases. Drugs (2006) 66:1371-87. doi:10.2165/00003495-200666100-00006

94. Jonkers D, Penders J, Masclee A, Pierik M. Probiotics in the management of inflammatory bowel disease: a systematic review of intervention studies in adult patients. Drugs (2012) 72:803-23. doi:10.2165/11632710-000000000-000003

95. Holubar SD, Cima RR, Sandborn WJ, Pardi DS. Treatment and prevention of pouchitis after ileal pouch-anal anastomosis for chronic ulcerative colitis. Cochrane Database Syst Rev (2010) 6:CD001176. doi:10.1002/14651858. CD001176.pub2

96. Wall GC, Schirmer LL, Anliker LE, Tigges AE. Pharmacotherapy for acute pouchitis. Ann Pharmacother (2011) 45:1127-37. doi:10.1345/aph.1P790

97. Camilleri M. Probiotics and irritable bowel syndrome: rationale, putative mechanisms, and evidence of clinical efficacy. J Clin Gastroenterol (2006) 40:264-9. doi:10.1097/00004836-200603000-00020

98. Mohan R, Koebnick C, Schildt J, Mueller M, Radke M, Blaut M. Effects of Bifidobacterium lactis Bb12 supplementation on body weight, fecal $\mathrm{pH}$, acetate, lactate, calprotectin, and IgA in preterm infants. Pediatr Res (2008) 64:418-22. doi:10.1203/PDR.0b013e318181b7fa

99. Wang Z, Wang J, Cheng Y, Liu X, Huang Y. Secreted factors from Bifidobacterium animalis subsp. lactis inhibit NF-kappaB-mediated interleukin8 gene expression in Caco-2 cells. Appl Environ Microbiol (2011) 77:8171-4. doi:10.1128/AEM.06145-11AEM.06145-11

100. Ruiz PA, Hoffmann M, Szcesny S, Blaut M, Haller D. Innate mechanisms for Bifidobacterium lactis to activate transient pro-inflammatory host responses in intestinal epithelial cells after the colonization of germ-free rats. Immunology (2005) 115:441-50. doi:10.1111/j.1365-2567.2005.02176.x

101. Mohan R, Koebnick C, Schildt J, Schmidt S, Mueller M, Possner M, et al. Effects of Bifidobacterium lactis Bb12 supplementation on intestinal microbiota of preterm infants: a double-blind, placebo-controlled, randomized study. J Clin Microbiol (2006) 44:4025-31. doi:10.1128/JCM.00767-06

102. Khailova L, Frank DN, Dominguez JA, Wischmeyer PE. Probiotic administration reduces mortality and improves intestinal epithelial homeostasis in experimental sepsis. Anesthesiology (2013) 119:166-77. doi:10.1097/ALN. 0b013e318291c2fc

103. Giahi L, Aumueller E, Elmadfa I, Haslberger AG. Regulation of TLR4, p38 MAPkinase, IkappaB and miRNAs by inactivated strains of lactobacilli in human dendritic cells. Benef Microbes (2012) 3:91-8. doi:10.3920/BM2011.0052

104. Kim SW, Park KY, Kim B, Kim E, Hyun CK. Lactobacillus rhamnosus GG improves insulin sensitivity and reduces adiposity in high-fat diet-fed mice through enhancement of adiponectin production. Biochem Biophys Res Commun (2013) 431:258-63. doi:10.1016/j.bbrc.2012.12.121

105. Yan F, Cao H, Cover TL, Washington MK, Shi Y, Liu L, et al. Colon-specific delivery of a probiotic-derived soluble protein ameliorates intestinal inflammation in mice through an EGFR-dependent mechanism. J Clin Invest (2011) 121:2242-53. doi:10.1172/JCI4403144031

106. Lin PW, Myers LE, Ray L, Song SC, Nasr TR, Berardinelli AJ, et al. Lactobacillus rhamnosus blocks inflammatory signaling in vivo via reactive oxygen species generation. Free Radic Biol Med (2009) 47:1205-11. doi:10.1016/j. freeradbiomed.2009.07.033

107. Seth A, Yan F, Polk DB, Rao RK. Probiotics ameliorate the hydrogen peroxideinduced epithelial barrier disruption by a PKC- and MAP kinase-dependent mechanism. Am J Physiol Gastrointest Liver Physiol (2008) 294:G1060-9. doi:10.1152/ajpgi.00202.2007

108. Ciprandi G, Vizzaccaro A, Cirillo I, Tosca MA. Bacillus clausii exerts immunomodulatory activity in allergic subjects: a pilot study. Eur Ann Allergy Clin Immunol (2005) 37:129-34.

109. Gabrielli M, Lauritano EC, Scarpellini E, Lupascu A, Ojetti V, Gasbarrini G, et al. Bacillus clausii as a treatment of small intestinal bacterial overgrowth. Am J Gastroenterol (2009) 104:1327-8. doi:10.1038/ajg.2009.91ajg200991
110. Urdaci MC, Bressollier P, Pinchuk I. Bacillus clausii probiotic strains: antimicrobial and immunomodulatory activities. J Clin Gastroenterol (2004) 38:S86-90. doi:10.1097/01.mcg.0000128925.06662.69

111. Castagliuolo I, Riegler MF, Valenick L, Lamont JT, Pothoulakis C. Saccharomyces boulardii protease inhibits the effects of Clostridium difficile toxins A and B in human colonic mucosa. Infect Immun (1999) 67:302-7.

112. Qamar A, Aboudola S, Warny M, Michetti P, Pothoulakis C, Lamont JT, et al. Saccharomyces boulardii stimulates intestinal immunoglobulin A immune response to Clostridium difficile toxin A in mice. Infect Immun (2001) 69:2762-5. doi:10.1128/IAI.69.4.2762-2765.2001

113. Pothoulakis C. Review article: anti-inflammatory mechanisms of action of Saccharomyces boulardii. Aliment Pharmacol Ther (2009) 30:826-33. doi:10.1111/ j.1365-2036.2009.04102.x

114. Buts JP, De Keyser N. Effects of Saccharomyces boulardii on intestinal mucosa. Dig Dis Sci (2006) 51:1485-92. doi:10.1007/s10620-005-9016-x

115. Dalmasso G, Cottrez F, Imbert V, Lagadec P, Peyron JF, Rampal P, et al. Saccharomyces boulardii inhibits inflammatory bowel disease by trapping $\mathrm{T}$ cells in mesenteric lymph nodes. Gastroenterology (2006) 131:1812-25. doi:10.1053/j.gastro.2006.10.001

116. Thomas S, Przesdzing I, Metzke D, Schmitz J, Radbruch A, Baumgart DC. Saccharomyces boulardii inhibits lipopolysaccharide-induced activation of human dendritic cells and T cell proliferation. Clin Exp Immunol (2009) 156:78-87. doi:10.1111/j.1365-2249.2009.03878.x

117. Rodrigues AC, Cara DC, Fretez SH, Cunha FQ, Vieira EC, Nicoli JR, et al. Saccharomyces boulardii stimulates sIgA production and the phagocytic system of gnotobiotic mice. J Appl Microbiol (2000) 89:404-14. doi:10.1046/j.1365-2672. 2000.01128.x

118. Martins FS, Silva AA, Vieira AT, Barbosa FH, Arantes RM, Teixeira MM, et al. Comparative study of Bifidobacterium animalis, Escherichia coli, Lactobacillus casei and Saccharomyces boulardii probiotic properties. Arch Microbiol (2009) 191:623-30. doi:10.1007/s00203-009-0491-x

119. Buts JP, Bernasconi P, Van Craynest MP, Maldague P, De Meyer R. Response of human and rat small intestinal mucosa to oral administration of Saccharomyces boulardii. Pediatr Res (1986) 20:192-6. doi:10.1203/00006450198602000-00020

120. Brandao RL, Castro IM, Bambirra EA, Amaral SC, Fietto LG, Tropia MJ, et al. Intracellular signal triggered by cholera toxin in Saccharomyces boulardii and Saccharomyces cerevisiae. Appl Environ Microbiol (1998) 64:564-8.

121. Gedek BR. Adherence of Escherichia coli serogroup O 157 and the Salmonella typhimurium mutant DT 104 to the surface of Saccharomyces boulardii. Mycoses (1999) 42:261-4. doi:10.1046/j.1439-0507.1999.00449.x

122. Martins FS, Vieira AT, Elian SD, Arantes RM, Tiago FC, Sousa LP, et al. Inhibition of tissue inflammation and bacterial translocation as one of the protective mechanisms of Saccharomyces boulardii against Salmonella infection in mice. Microbes Infect (2013) 15:270-9. doi:10.1016/j.micinf.2012.12.007

123. Chen X, Kokkotou EG, Mustafa N, Bhaskar KR, Sougioultzis S, O'Brien $\mathrm{M}$, et al. Saccharomyces boulardii inhibits ERK1/2 mitogen-activated protein kinase activation both in vitro and in vivo and protects against Clostridium difficile toxin A-induced enteritis. J Biol Chem (2006) 281:24449-54. doi:10.1074/jbc.M605200200

124. Martins FS, Dalmasso G, Arantes RM, Doye A, Lemichez E, Lagadec P, et al. Interaction of Saccharomyces boulardii with Salmonella enterica serovar typhimurium protects mice and modifies T84 cell response to the infection. PLoS One (2010) 5:e8925. doi:10.1371/journal.pone.0008925

125. Wu X, Vallance BA, Boyer L, Bergstrom KS, Walker J, Madsen K, et al. Saccharomyces boulardii ameliorates Citrobacter rodentium-induced colitis through actions on bacterial virulence factors. Am J Physiol Gastrointest Liver Physiol (2008) 294:G295-306. doi:10.1152/ajpgi.00173.2007

126. Pontier-Bres R, Prodon F, Munro P, Rampal P, Lemichez E, Peyron JF, et al. Modification of Salmonella typhimurium motility by the probiotic yeast strain Saccharomyces boulardii. PLoS One (2012) 7:e33796. doi:10.1371/journal.pone. 0033796

127. Generoso SV, Viana ML, Santos RG, Arantes RM, Martins FS, Nicoli JR, et al. Protection against increased intestinal permeability and bacterial translocation induced by intestinal obstruction in mice treated with viable and heat-killed Saccharomyces boulardii. Eur J Nutr (2011) 50:261-9. doi:10.1007/s00394-0100134-7 
128. Imase K, Takahashi M, Tanaka A, Tokunaga K, Sugano H, Tanaka M, et al. Efficacy of Clostridium butyricum preparation concomitantly with Helicobacter pylori eradication therapy in relation to changes in the intestinal microbiota. Microbiol Immunol (2008) 52:156-61. doi:10.1111/j.1348-0421.2008.00026.x

129. Woo TD, Oka K, Takahashi M, Hojo F, Osaki T, Hanawa T, et al. Inhibition of the cytotoxic effect of Clostridium difficile in vitro by Clostridium butyricum MIYAIRI 588 strain. J Med Microbiol (2011) 60:1617-25. doi:10.1099/jmm.0.033423-0

130. Takahashi M, Taguchi H, Yamaguchi H, Osaki T, Komatsu A, Kamiya S. The effect of probiotic treatment with Clostridium butyricum on enterohemorrhagic Escherichia coli O157:H7 infection in mice. FEMS Immunol Med Microbiol (2004) 41:219-26. doi:10.1016/j.femsim.2004.03.010

131. Hayashi A, Sato T, Kamada N, Mikami Y, Matsuoka K, Hisamatsu T, et al. A Single Strain of Clostridium butyricum Induces Intestinal IL-10-Producing Macrophages to Suppress Acute Experimental Colitis in Mice. Cell Host Microbe (2013) 13:711-22. doi:10.1016/j.chom.2013.05.013

132. Schultz M. Clinical use of E. coli Nissle 1917 in inflammatory bowel disease. Inflamm Bowel Dis (2008) 14:1012-8. doi:10.1002/ibd.20377

133. Troge A, Scheppach W, Schroeder BO, Rund SA, Heuner K, Wehkamp J, et al. More than a marine propeller - the flagellum of the probiotic Escherichia coli strain Nissle 1917 is the major adhesin mediating binding to human mucus. Int J Med Microbiol (2012) 302:304-14. doi:10.1016/j.ijmm.2012.09.004

134. Schierack P, Kleta S, Tedin K, Babila JT, Oswald S, Oelschlaeger TA, et al. E. coli Nissle 1917 affects Salmonella adhesion to porcine intestinal epithelial cells. PLoS One (2011) 6:e14712. doi:10.1371/journal.pone.0014712

135. Altenhoefer A, Oswald S, Sonnenborn U, Enders C, Schulze J, Hacker J, et al. The probiotic Escherichia coli strain Nissle 1917 interferes with invasion of human intestinal epithelial cells by different enteroinvasive bacterial pathogens. FEMS Immunol Med Microbiol (2004) 40:223-9. doi:10.1016/S0928-8244(03) 00368-7

136. Zyrek AA, Cichon C, Helms S, Enders C, Sonnenborn U, Schmidt MA. Molecular mechanisms underlying the probiotic effects of Escherichia coli Nissle 1917 involve ZO-2 and PKCzeta redistribution resulting in tight junction and epithelial barrier repair. Cell Microbiol (2007) 9:804-16. doi:10.1111/j.14625822.2006.00836.x

137. Dai C, Zheng CQ, Meng FJ, Zhou Z, Sang LX, Jiang M. VSL\#3 probiotics exerts the anti-inflammatory activity via PI3k/Akt and NF-kappaB pathway in rat model of DSS-induced colitis. Mol Cell Biochem (2013) 374:1-11. doi:10.1007/s11010-012-1488-3

138. Soo I, Madsen KL, Tejpar Q, Sydora BC, Sherbaniuk R, Cinque B, et al. VSL\#3 probiotic upregulates intestinal mucosal alkaline sphingomyelinase and reduces inflammation. Can J Gastroenterol (2008) 22:237-42.

139. Mennigen R, Nolte K, Rijcken E, Utech M, Loeffler B, Senninger N, et al. Probiotic mixture VSL\#3 protects the epithelial barrier by maintaining tight junction protein expression and preventing apoptosis in a murine model of colitis. Am J Physiol Gastrointest Liver Physiol (2009) 296:G1140-9. doi:10.1152/ajpgi. 90534.2008

140. Dai C, Zhao DH, Jiang M. VSL\#3 probiotics regulate the intestinal epithelial barrier in vivo and in vitro via the p38 and ERK signaling pathways. Int J Mol Med (2012) 29:202-8. doi:10.3892/ijmm.2011.839

141. Dharmani P, De Simone C, Chadee K. The probiotic mixture VSL\#3 accelerates gastric ulcer healing by stimulating vascular endothelial growth factor. PLoS One (2013) 8:e58671. doi:10.1371/journal.pone.0058671

142. Uronis JM, Arthur JC, Keku T, Fodor A, Carroll IM, Cruz ML, et al. Gut microbial diversity is reduced by the probiotic VSL\#3 and correlates with decreased TNBS-induced colitis. Inflamm Bowel Dis (2011) 17:289-97. doi:10.1002/ibd. 21366

143. Vitali B, Ndagijimana M, Maccaferri S, Biagi E, Guerzoni ME, Brigidi P. An in vitro evaluation of the effect of probiotics and prebiotics on the metabolic profile of human microbiota. Anaerobe (2012) 18:386-91. doi:10.1016/j. anaerobe.2012.04.014

144. Schiavi E, Barletta B, Butteroni C, Corinti S, Boirivant M, Di Felice G. Oral therapeutic administration of a probiotic mixture suppresses established Th2 responses and systemic anaphylaxis in a murine model of food allergy. Allergy (2011) 66:499-508. doi:10.1111/j.1398-9995.2010.02501.x

145. Thang CL, Boye JI, Zhao X. Low doses of allergen and probiotic supplementation separately or in combination alleviate allergic reactions to cow betalactoglobulin in mice. J Nutr (2013) 143:136-41. doi:10.3945/jn.112.169466
146. Madsen KL. The use of probiotics in gastrointestinal disease. Can J Gastroenterol (2001) 15:817-22.

147. Bibiloni R, Fedorak RN, Tannock GW, Madsen KL, Gionchetti P, Campieri M, et al. VSL\#3 probiotic-mixture induces remission in patients with active ulcerative colitis. Am J Gastroenterol (2005) 100:1539-46. doi:10.1111/j.1572-0241. 2005.41794.x

148. Sanders ME, Akkermans LM, Haller D, Hammerman C, Heimbach J, Hormannsperger G, et al. Safety assessment of probiotics for human use. Gut Microbes (2010) 1:164-85. doi:10.4161/gmic.1.3.12127

149. Fukuda S, Toh H, Taylor TD, Ohno H, Hattori M. Acetate-producing bifidobacteria protect the host from enteropathogenic infection via carbohydrate transporters. Gut Microbes (2012) 3:449-54. doi:10.4161/gmic.21214

150. Fukuda S, Toh H, Hase K, Oshima K, Nakanishi Y, Yoshimura K, et al. Bifidobacteria can protect from enteropathogenic infection through production of acetate. Nature (2011) 469:543-7. doi:10.1038/nature

151. Martins FS, Rodrigues AC, Tiago FC, Penna FJ, Rosa CA, Arantes RM, et al. Saccharomyces cerevisiae strain 905 reduces the translocation of Salmonella enterica serotype typhimurium and stimulates the immune system in gnotobiotic and conventional mice. J Med Microbiol (2007) 56:352-9. doi:10.1099/jmm.0.46525-0

152. Martins FS, Elian SD, Vieira AT, Tiago FC, Martins AK, Silva FC, et al. Oral treatment with Saccharomyces cerevisiae strain UFMG 905 modulates immune responses and interferes with signal pathways involved in the activation of inflammation in a murine model of typhoid fever. Int J Med Microbiol (2011) 301:359-64. doi:10.1016/j.ijmm.2010.11.002

153. Martins AK, Martins FS, Gomes DA, Elian SD, Vieira AT, Teixeira MM, et al. Evaluation of in vitro antagonism and of in vivo immune modulation and protection against pathogenic experimental challenge of two probiotic strains of Bifidobacterium animalis var. lactis. Arch Microbiol (2010) 192:995-1003. doi:10.1007/s00203-010-0626-0

154. Tiago FC, Martins FS, Souza EL, Pimenta PF, Araujo HR, Castro IM, et al. Adhesion to the yeast cell surface as a mechanism for trapping pathogenic bacteria by Saccharomyces probiotics. J Med Microbiol (2012) 61:1194-207. doi:10.1099/jmm.0.042283-0

155. Theodorakopoulou M, Perros E, Giamarellos-Bourboulis EJ, Dimopoulos G. Controversies in the management of the critically ill: the role of probiotics. Int J Antimicrob Agents (2013) 42(Suppl):S41-4. doi:10.1016/j.ijantimicag. 2013.04.010

156. Gibson GR, Probert HM, Loo JV, Rastall RA, Roberfroid MB. Dietary modulation of the human colonic microbiota: updating the concept of prebiotics. Nutr Res Rev (2004) 17:259-75. doi:10.1079/NRR200479

157. Gloux K, Berteau O, El Oumami H, Beguet F, Leclerc M, Dore J. A metagenomic beta-glucuronidase uncovers a core adaptive function of the human intestinal microbiome. Proc Natl Acad Sci U S A (2011) 108(Suppl 1):4539-46. doi:10.1073/pnas.10000661071000066107

158. McNeil NI, Cummings JH, James WP. Short chain fatty acid absorption by the human large intestine. Gut (1978) 19:819-22. doi:10.1136/gut.19.9.819

159. Scott KP, Gratz SW, Sheridan PO, Flint HJ, Duncan SH. The influence of diet on the gut microbiota. Pharmacol Res (2013) 69:52-60. doi:10.1016/j.phrs.2012. 10.020

160. Mahowald MA, Rey FE, Seedorf H, Turnbaugh PJ, Fulton RS, Wollam A, et al. Characterizing a model human gut microbiota composed of members of its two dominant bacterial phyla. Proc Natl Acad Sci U S A (2009) 106:5859-64. doi:10.1073/pnas.0901529106

161. Arumugam M, Raes J, Pelletier E, Le Paslier D, Yamada T, Mende DR, et al. Enterotypes of the human gut microbiome. Nature (2011) 473:174-80. doi:10.1038/nature09944

162. Emilia H, Viktoria S, Jana S, Gabriela H. Chemopreventive and metabolic effects of inulin in colon cancer development. J Vet Sci (2013).

163. Macfarlane GT, Steed H, Macfarlane S. Bacterial metabolism and health-related effects of galacto-oligosaccharides and other prebiotics. JAppl Microbiol (2008) 104:305-44. doi:10.1111/j.1365-2672.2007.03520.x

164. Ramirez-Farias C, Slezak K, Fuller Z, Duncan A, Holtrop G, Louis P. Effect of inulin on the human gut microbiota: stimulation of Bifidobacterium adolescentis and Faecalibacterium prausnitzii. Br J Nutr (2009) 101:541-50. doi:10.1017/S0007114508019880

165. Hopping BN, Erber E, Grandinetti A, Verheus M, Kolonel LN, Maskarinec G. Dietary fiber, magnesium, and glycemic load alter risk of type 2 diabetes in 
a multiethnic cohort in Hawaii. J Nutr (2010) 140:68-74. doi:10.3945/jn.109. 112441

166. Costabile A, Kolida S, Klinder A, Gietl E, Bauerlein M, Frohberg C, et al. A double-blind, placebo-controlled, cross-over study to establish the bifidogenic effect of a very-long-chain inulin extracted from globe artichoke (Cynara scolymus) in healthy human subjects. Br J Nutr (2010) 104:1007-17. doi:10.1017/S0007114510001571

167. Ramnani P, Gaudier E, Bingham M, van Bruggen P, Tuohy KM, Gibson GR. Prebiotic effect of fruit and vegetable shots containing Jerusalem artichoke inulin: a human intervention study. Br J Nutr (2010) 104:233-40. doi:10.1017/S000711451000036X

168. Scholtens PA, Alles MS, Bindels JG, van der Linde EG, Tolboom JJ, Knol J. Bifidogenic effects of solid weaning foods with added prebiotic oligosaccharides: a randomised controlled clinical trial. J Pediatr Gastroenterol Nutr (2006) 42:553-9. doi:10.1097/01.mpg.0000221887.28877.c7

169. Benjamin JL, Hedin CR, Koutsoumpas A, Ng SC, McCarthy NE, Hart $\mathrm{AL}$, et al. Randomised, double-blind, placebo-controlled trial of fructooligosaccharides in active Crohn's disease. Gut (2011) 60:923-9. doi:10.1136/ gut.2010.232025gut

170. de Luis DA, de la Fuente B, Izaola O, Conde R, Gutierrez S, Morillo M, et al. Double blind randomized clinical trial controlled by placebo with an alpha linoleic acid and prebiotic enriched cookie on risk cardiovascular factor in obese patients. Nutr Hosp (2011) 26:827-33. doi:10.1590/S021216112011000400024

171. Cummings JH, Christie S, Cole TJ. A study of fructo oligosaccharides in the prevention of travellers' diarrhoea. Aliment Pharmacol Ther (2001) 15:1139-45. doi:10.1046/j.1365-2036.2001.01043.x

172. Arslanoglu S, Moro GE, Schmitt J, Tandoi L, Rizzardi S, Boehm G. Early dietary intervention with a mixture of prebiotic oligosaccharides reduces the incidence of allergic manifestations and infections during the first two years of life. J Nutr (2008) 138:1091-5.

173. Boutron-Ruault MC, Marteau P, Lavergne-Slove A, Myara A, Gerhardt MF, Franchisseur C, et al. Effects of a 3-mo consumption of short-chain fructooligosaccharides on parameters of colorectal carcinogenesis in patients with or without small or large colorectal adenomas. Nutr Cancer (2005) 53:160-8. doi:10.1207/s15327914nc5302_5

174. Saavedra JM, Tschernia A. Human studies with probiotics and prebiotics: clinical implications. Br J Nutr (2002) 87(Suppl 2):S241-6. doi:10.1079/BJNBJN/ 2002543

175. Drakoularakou A, Tzortzis G, Rastall RA, Gibson GR. A double-blind, placebocontrolled, randomized human study assessing the capacity of a novel galactooligosaccharide mixture in reducing travellers' diarrhoea. Eur J Clin Nutr (2010) 64:146-52. doi:10.1038/ejcn.2009.120

176. Peng X, Li S, Luo J, Wu X, Liu L. Effects of dietary fibers and their mixtures on short chain fatty acids and microbiota in mice guts. Food Funct (2013) 4:932-8. doi:10.1039/c3fo60052a

177. Slavin J. Fiber and prebiotics: mechanisms and health benefits. Nutrients (2013) 5:1417-35. doi:10.3390/nu5041417

178. Chen H, Mao X, He J, Yu B, Huang Z, Yu J, et al. Dietary fibre affects intestinal mucosal barrier function and regulates intestinal bacteria in weaning piglets. Br J Nutr (2013) 110:1837-48. doi:10.1017/S0007114513001293

179. Hu GX, Chen GR, Xu H, Ge RS, Lin J. Activation of the AMP activated protein kinase by short-chain fatty acids is the main mechanism underlying the beneficial effect of a high fiber diet on the metabolic syndrome. Med Hypotheses (2010) 74:123-6. doi:10.1016/j.mehy.2009.07.022

180. Cao Y, Gao X, Zhang W, Zhang G, Nguyen AK, Liu X, et al. Dietary fiber enhances TGF-beta signaling and growth inhibition in the gut. Am J Physiol Gastrointest Liver Physiol (2011) 301:G156-64. doi:10.1152/ajpgi.00362

181. Slavin JL. Position of the American Dietetic Association: health implications of dietary fiber. J Am Diet Assoc (2008) 108:1716-31. doi:10.1016/j.jada.2008. 08.007

182. Frank DN, St Amand AL, Feldman RA, Boedeker EC, Harpaz N, Pace NR. Molecular-phylogenetic characterization of microbial community imbalances in human inflammatory bowel diseases. Proc Natl Acad Sci U S A (2007) 104:13780-5. doi:10.1073/pnas.0706625104

183. Maslowski KM, Vieira AT, Ng A, Kranich J, Sierro F, Yu D, et al. Regulation of inflammatory responses by gut microbiota and chemoattractant receptor GPR43. Nature (2009) 461:1282-6. doi:10.1038/nature08530
184. Hamer HM, Jonkers DM, Vanhoutvin SA, Troost FJ, Rijkers G, De Bruine A, et al. Effect of butyrate enemas on inflammation and antioxidant status in the colonic mucosa of patients with ulcerative colitis in remission. Clin Nutr (2010) 29:738-44. doi:10.1016/j.clnu.2010.04.002

185. Huda-Faujan N, Abdulamir AS, Fatimah AB, Anas OM, Shuhaimi M, Yazid AM, et al. The impact of the level of the intestinal short chain Fatty acids in inflammatory bowel disease patients versus healthy subjects. Open Biochem $J$ (2010) 4:53-8. doi:10.2174/1874091X01004010053

186. Gibson PR, Rosella O, Wilson AJ, Mariadason JM, Rickard K, Byron K, et al. Colonic epithelial cell activation and the paradoxical effects of butyrate. Carcinogenesis (1999) 20:539-44. doi:10.1093/carcin/20.4.539

187. Wang HB, Wang PY, Wang X, Wan YL, Liu YC. Butyrate enhances intestinal epithelial barrier function via up-regulation of tight junction protein Claudin-1 transcription. Dig Dis Sci (2012) 57:3126-35. doi:10.1007/s10620-012-2259-4

188. Ritzhaupt A, Wood IS, Ellis A, Hosie KB, Shirazi-Beechey SP. Identification and characterization of a monocarboxylate transporter (MCT1) in pig and human colon: its potential to transport L-lactate as well as butyrate. J Physiol (1998) 513(Pt 3):719-32. doi:10.1111/j.1469-7793.1998.719ba.x

189. Davie JR. Inhibition of histone deacetylase activity by butyrate. J Nutr (2003) 133:2485S-93S.

190. Klampfer L, Huang J, Sasazuki T, Shirasawa S, Augenlicht L. Inhibition of interferon gamma signaling by the short chain fatty acid butyrate. Mol Cancer Res (2003) 1:855-62.

191. Luhrs H, Gerke T, Muller JG, Melcher R, Schauber J, Boxberge F, et al. Butyrate inhibits NF-kappaB activation in lamina propria macrophages of patients with ulcerative colitis. Scand J Gastroenterol (2002) 37:458-66. doi:10.1080/ 003655202317316105

192. Schwab M, Reynders V, Ulrich S, Zahn N, Stein J, Schroder O. PPARgamma is a key target of butyrate-induced caspase-3 activation in the colorectal cancer cell line Caco-2. Apoptosis (2006) 11:1801-11. doi:10.1007/s10495-006-9788-2

193. Su CG, Wen X, Bailey ST, Jiang W, Rangwala SM, Keilbaugh SA, et al. A novel therapy for colitis utilizing PPAR-gamma ligands to inhibit the epithelial inflammatory response. J Clin Invest (1999) 104:383-9. doi:10.1172/JCI7145

194. Kim MH, Kang SG, Park JH, Yanagisawa M, Kim CH. Short-chain fatty acids activate GPR41 and GPR43 on intestinal epithelial cells to promote inflammatory responses in mice. Gastroenterology (2013) 145:396-406. doi:10.1053/ j.gastro.2013.04.056S0016-5085(13)00708-7

195. Smith PM, Howitt MR, Panikov N, Michaud M, Gallini CA, Bohlooly YM, et al. The microbial metabolites, short-chain fatty acids, regulate colonic Treg cell homeostasis. Science (2013) 341(6145):569-73. doi:10.1126/science.1241165

196. Brown AJ, Goldsworthy SM, Barnes AA, Eilert MM, Tcheang L, Daniels D, et al. The Orphan G protein-coupled receptors GPR41 and GPR43 are activated by propionate and other short chain carboxylic acids. J Biol Chem (2003) 278:11312-9. doi:10.1074/jbc.M211609200

197. Gibson GR, Roberfroid MB. Dietary modulation of the human colonic microbiota: introducing the concept of prebiotics. J Nutr (1995) 125:1401-12.

198. Aslam MN, Bergin I, Naik M, Paruchuri T, Hampton A, Rehman M, et al. A multimineral natural product from red marine algae reduces colon polyp formation in C57BL/6 mice. Nutr Cancer (2012) 64:1020-8. doi:10.1080/01635581. 2012.713160

Conflict of Interest Statement: The authors declare that the research was conducted in the absence of any commercial or financial relationships that could be construed as a potential conflict of interest.

Received: 09 September 2013; accepted: 26 November 2013; published online: 12 December 2013.

Citation: Vieira AT, Teixeira MM and Martins FS (2013) The role of probiotics and prebiotics in inducing gut immunity. Front. Immunol. 4:445. doi: 10.3389/fimmu.2013.00445

This article was submitted to Mucosal Immunity, a section of the journal Frontiers in Immunology.

Copyright $\odot 2013$ Vieira, Teixeira and Martins. This is an open-access article distributed under the terms of the Creative Commons Attribution License (CC BY). The use, distribution or reproduction in other forums is permitted, provided the original author (s) or licensor are credited and that the original publication in this journal is cited, in accordance with accepted academic practice. No use, distribution or reproduction is permitted which does not comply with these terms. 